\title{
The Law Enforcement against the Personnel of Corruption Crime
}

\section{Haris Fadillah Harahap*) and Widayati**)}

*) Student Master of Law, Faculty of Law, Universitas Islam Sultan Agung Semarang and Prosecutor of Pemalang District Attorney, E-mail: harisfh_mh35@std.unissula.ac.id

${ }^{* *}$ ) Faculty of Law Universitas Islam Sultan Agung

\begin{abstract}
.
The purpose of this research is to analyze and explain: 1) Implementation of law enforcement against perpetrators of corruption in the jurisdiction of the Pemalang District Prosecutor's Office, 2) Efforts made by the Prosecutor in preventing the occurrence of criminal acts of corruption in the jurisdiction of the Pemalang District Attorney that hinders law enforcement against perpetrators of corruption in the jurisdiction of the Pemalang District Prosecutor's Office and the solution. The approach method used in this study is a sociological juridical approach. The sociological juridical approach method is used to study/analyze secondary data in the form of legal materials, especially primary legal materials and secondary legal materials. The results showed that the implementation of law enforcement against perpetrators of corruption in the jurisdiction of the Pemalang District Prosecutor's Office noted that carry out several processes or stages in accordance with the laws and regulations and the Prosecutor's Standard Operating Procedure (SOP), namely examination, investigation, investigation and prosecution. As for prosecution, in addition to criminal efforts, efforts were also made to force the return of money from corruption to be returned to the state treasury. As for the efforts made by the Prosecutor in preventing the occurrence of criminal acts of corruption in the jurisdiction of the Pemalang District Prosecutor's Office, namely through comprehensive policies and comprehensive administrative reform in the form of privatization, deregulation, and decentralization. Factors that hinder law enforcement against perpetrators Criminal acts of corruption in the jurisdiction of the Pemalang District Attorney are the complexity of corruption cases, time constraints, the intensity of examinations by the limited functional supervisory apparatus, the spread of corruption cases through public policies, and the level of public legal awareness is still relatively low.

Keyword: Law Enforcement; Corruption Crime; Prosecutors.
\end{abstract}

\section{Introduction}

Indonesia is a rule of law country, this has been clearly stated in the explanation of Article 1 paragraph (3) of the 1945 Constitution of the Republic of Indonesia that "Indonesia is a state of law ${ }^{1}$, meaning that everything related to the life of the community, nation and state is regulated according to applicable law.

According to Sri Endah Wahyuningsih and Rismanto², a rule of law is a state that enforces the law optimally, upholds human rights and which guarantees that

\footnotetext{
${ }^{1}$ See Article 1 paragraph (3) of the 1945 Constitution of the Republic of Indonesia

2 Sri Endah Wahyuningsih and Rismanto. (2016). Kebijakan Penegakan Hukum Pidana Terhadap Penanggulangan Money Laundring Dalam Rangka Pembaharuan Hukum Pidana Di Indonesia, Universitas Islam Sultan Agung Semarang.
} 
citizens have equal position in the law and that the government is obliged to uphold the law and government without exception. So law enforcement is one of the parameters in the success of a rule of law.

Corruption is one of the terms that are now familiar to the Indonesian people. In the criminology literature, corruption is a type of "white collar crime". The familiarity of the term corruption in the community has shown the proliferation of public attention to corruption, "white collar crime" is able to attract public attention because the perpetrators are people who are perceived by society as well-known or well-respected people but they are the ones who create squalor in society. ${ }^{3}$

The incidence of corruption-type crimes, according to JE Sahetapi, was quoted by Usman in his journal, which revealed that: "The emergence of corruption-type crimes shows that not only poverty is the cause of crime, but prosperity and luxury are the driving factors for people to commit corruption crimes." 4

The term corruption itself comes from the Latin "ciruptio" or "coruptus", which means damage or depravity, literally the meaning of corruption itself is rottenness, depravity, dishonesty, can be bribed, deviation from holiness and in Indonesian the word corruption is a bad act, such as embezzlement of money, receipt of money and so on. ${ }^{5}$

To carry out the task of eradicating corruption, the AGO cannot work alone by relying on the ability of the prosecutor's apparatus without cooperating with other agencies. Therefore, the cooperation between the Police and the Prosecutors in Pemalang is very much needed in dealing with criminal acts of corruption in Pemalang.

Seeing the above phenomena, the authors are interested in further examining the implementation of law enforcement against perpetrators of corruption, the efforts made by prosecutors in preventing the occurrence of criminal acts of corruption, and factors that hinder law enforcement against perpetrators of criminal acts of corruption and the solution.

Based on the description of the background of the problem above, the authors propose the formulation of the problem: How is the implementation of law enforcement against perpetrators of corruption? What are the efforts made by the prosecutor in preventing the occurrence of criminal acts of corruption? What factors hinder law enforcement against perpetrators of criminal acts of corruption and what are the solutions?

\section{Research methods}

\footnotetext{
3 Teguh Sulista and Aria Zurnetti. (2011). Hukum Pidana: Horizon Baru Pasca Reformasi, Jakarta. PT. Raja Grafindo Persada. p. 63

4 Usman. 2013, "Analisis Perkembangan Teori Hukum Pidana". Jurnal Ilmu Hukum.Volume 2 Nomor 1. Juni 2013. p. 68.

${ }^{5}$ Aluysius Sutikna, Sri Kusriyah, Widayati. 2018. Implementation of Act No. 30 Year 2014 concerning Government Administration Against Corruption Crime Investigation Process at Rembang Police, Jurnal Hukum Khaira Ummah Vol. 13. No. March 1, 2018. p. 23
} 
The approach method used in this study is a sociological juridical approach. The sociological juridical approach method is used to study/analyze secondary data in the form of legal materials, especially primary legal materials and secondary legal materials 6 .

The research specification in this research is descriptive, that is, a study that only describes the object which is the main problem 7 . In this study, the author will describe how law enforcement in corruption cases in Pemalang.Data analysis in this study used qualitative methods. Research using qualitative methods departs from assumptions about reality or social phenomena that are unique and complex. In it there is a certain regularity or pattern, but it is full of variation (diversity). ${ }^{8}$

\section{Results and Discussion}

\subsection{Implementation of Law Enforcement Against Corruption Criminal Actors}

According to Guntur Setiawan in his book expressed his opinion regarding the implementation or implementation as follows:

"Implementation is the expansion of activities that mutually adjust the process of interaction between goals and actions to achieve them and requires a network of implementers, an effective bureaucracy". ${ }^{9}$

According to the explanation of Tati Vain Sitanggang, SH, MH that, Pemalang District Attorney in Implementing Law Enforcement Against Corruption Perpetrators through the Corruption Crime investigation mechanism, namely ${ }^{10}$ :

- Investigation/Preliminary Examination

The preliminary examination process is in the form of activities that are detailed in the form of preparatory examinations, namely investigations. Investigation is a series of actions by an investigator to search for and discover an event that is suspected of being a criminal act in order to determine whether or not an investigation can be carried out according to methods regulated in this Law (Article 1 paragraph (5) KUHAP).

- Investigation

Investigation is a series of actions by an investigator in terms and according to the manner regulated in this law to seek and collect evidence with that evidence to make clear a criminal act that has occurred in order to find the suspect. ${ }^{11}$

- Prosecution

Prosecution is an action by a public prosecutor to delegate a criminal case to the competent District Court in matters and according to the manner regulated in law by requesting that it be examined and decided by a judge in court. ${ }^{12}$

\footnotetext{
${ }^{6}$ Hanitijo, Ronny. (1990). Metode Penelitian Hukum dan Jurimetri. Jakarta: Ghalia Indonesia. p. 1112.

${ }^{7}$ Ronny Hanitijo, 1990, Metode Penelitian Hukum dan Jurimetri, Ghalia Indonesia, Jakarta, p. 13

8 Bungi, Burhan. (2003). Analisa Data Penelitian Kualitatif, Pemahaman Filosofis dan Metodologis Kearah Penguasaan Modal Aplikasi. Jakarta: PT. Raja Grafindo Persada. p. 53.

${ }^{9}$ Setiawan, Guntur. (2014). Impelemtasi dalam Birokrasi Pembangunan. Jakarta: Balai Pustaka. p. 39

10 The results of the author's interview with Tati Vain Sitanggang, SH, MH as the Head of the Pemalang District Prosecutor's Office, on September 22, 2020.

11 See Article 1 Paragraph (2) of the Criminal Procedure Code.
} 
- Final Inspection

- Reading of the Indictment

- Exception (Article 156 KUHAP).

- Examination of Witnesses and Expert Witnesses

- Statement of the Defendant (Articles 177-178 of the Criminal Procedure Code).

- Proof

- Requisitoir or Criminal Charges (Article 187 letter a KUHAP).

- Pledoi (Article 196 paragraph (3) KUHAP)

- Replik-Duplic (Article 182 paragraph (1) KUHAP)

- Conclusion

- Sentence

This is in line with Rully Trie Prasetyo, Umar Ma'ruf, Anis Mashdurohatun that the scope of law enforcement includes Restorative justice, which is a settlement process carried out outside the criminal justice system by involving victims, perpetrators, and families of victims and the public and parties with an interest in a criminal act that occurs in order to reach an agreement and settlement ${ }^{13}$. Restorative justice is considered a new way of thinking/paradigm in seeing a crime committed by a person. ${ }^{14}$

\subsection{The efforts made by the prosecutor in preventing the occurrence of criminal acts of corruption}

According to the explanation of Tati Vain Sitanggang, $\mathrm{SH}, \mathrm{MH}$, that in the framework of preventing and eradicating corruption in the future, there are four things that can be used as material for reflection and thoughts:

- Harmonization of laws and regulations in the context of preventing and eradicating corruption.

- Revitalization and re-actualization of the roles and functions of law enforcement officials who handle corruption cases.

- Reformulation of the functions of the legislature.

- Eradicating corruption crimes must start from small things and start today so that every region is free from corruption. ${ }^{15}$

The position of the Prosecutor's Office in criminal justice is quite important because it is a bridge that connects the investigation stage with the examination stage at court proceedings. Based on the prevailing legal doctrine, the public prosecutor has a monopoly on prosecution, meaning that every person can only be tried if there is a criminal charge from the public prosecutor, namely the

\footnotetext{
12 See Article 1 point 7 of the Criminal Procedure Code.

13 Rully Trie Prasetyo, Umar Ma'ruf, Anis Mashdurohatun, 2017, Tindak Pidana Korporasi Dalam Perspektif Kebijakan Formulasi Hukum Pidana, Jurnal Hukum Khaira Ummah, Vol 12, No.4, Universitas Islam Sultan Agung Semarang, p. 727-741.

14 Ibid

15 The results of the author's interview with Ms. Tati Vain Sitanggang, SH, MH, as the Head of the Pemalang District Prosecutor's Office, on September 24, 2020.
} 
prosecutor's office because only the public prosecutor has the authority to propose a suspect status to the perpetrator of a criminal act before the trial. ${ }^{16}$

Corruption is included in a special crime. The term corruption comes from "Corruption" which means damage. In addition, the sentence of corruption is also used to denote a bad condition or act. Corruption is mostly attributed to someone being dishonest in the financial sector. ${ }^{17}$

Law enforcement is an effort to tackle crime rationally, fulfill justice and be efficient, in the context of tackling crimes against various means as a reaction that can be given to criminals, in the form of criminal and non-criminal legal means, which can be integrated with one another. If criminal means are called to tackle crimes, it means that criminal law politics will be implemented, namely holding elections to achieve results of criminal legislation that are in accordance with the circumstances and situations at one time and for the future ${ }^{18}$

According to the authors studied in the theory of the legal system that the prevention of corruption still occurs massively and systematically. The practice can take place anywhere, in state institutions, private institutions, to everyday life. Seeing such conditions, prevention is worthy of being the first strategy. Through a prevention strategy, it is hoped that sustainable steps will emerge that contribute to future improvements.

In addition, the Attorney General's Office must also be more dominant in cooperation with other institutions, for example with the Police in efforts to prevent criminal acts of corruption.

In the field of criminal law, the police are law enforcement officers who are tasked with maintaining order and ensuring public security, maintaining state safety and public safety, including providing protection and assistance and providing and endeavoring to comply with citizens and society with all forms of regulations ${ }^{19}$

\subsection{Factors that hinder law enforcement against perpetrators of corruption and their solutions}

Law enforcement carried out by the Pemalang District Attorney is closely related to the criminal act of corruption in practice facing various obstacles/obstacles, especially in optimizing the eradication of corruption. This is due to, among others ${ }^{20}$ :

- The complexity of corruption cases.

- Time constraints, the occurrence of corruption is generally long, so it is difficult to prove it.

\footnotetext{
16 Kristiana, Yudi. (2006). Independensi Kejaksaan dalam Penyidikan Korupsi. Bandung: PT Citra Aditya Bakti. p. 52.

17 Sutarto. (2014). Hukum Acara Pidana Jilid I. Semarang: Universitas Diponegoro

18 Sudarto. (2010). Hukum Pidana dan Perkembangan Masyarakat. Bandung: Sinar Baru. p. 3.

19 Zaenul Arifin, Sri Endah Wahyuningsih, Sri Kusriyah, 2017, The Process of Law Enforcement Against Criminal Actors, Khaira Ummah Legal Journal Vol. 12. No. 4 December 2017: 777-784

20 The results of the author's interview with Mrs. Tati Vain Sitanggang, SH, MH, as the Head of the Pemalang District Prosecutor's Office, on September 25, 2020
} 
- The intensity of examinations by the functional supervisory apparatus is limited.

- The spread of corruption cases through public policies.

Implications of the weak law enforcement of the Corruption Crime. This condition is made possible by several factors, among others ${ }^{21}$ :

- The perpetrators of corruption operate in a sophisticated, sneaky manner and cannot be detected by radar and law enforcement tools.

- Limited human resources, especially prosecutors, to handle investigations into corruption cases, so that prosecutors have not been able to carry out investigations optimally.

- Weaknesses in investigations and law enforcement investigations in finding more authentic evidence that makes it difficult to bring corruptors to court.

The Indonesian criminal law system still does not fully recognize that corporations are accountable legal subjects. Although there are several products of criminal law policies outside the Criminal Code that regulate corporate responsibility, the corporate responsibility system that is adopted still uses the vicarious liability doctrine, this is the same as not recognizing corporations as subjects of criminal law. Therefore, it is necessary to recommend a policy reformulation on the corporate criminal liability system and include this formulation in the Criminal Code. ${ }^{22}$

Reorientation and reformulation of criminal responsibility for victims of corporate crimes include provisions regarding:

- Provisions regarding when a criminal act can be said to be a criminal act committed by a corporation;

- Who can be prosecuted and convicted for crimes committed by the corporation;

- Types of sanctions that suit the subject of a criminal act in the form of a corporation that is oriented towards providing compensation to victims. ${ }^{23}$

Based on the description above, it can be concluded that the obstacles faced by the Pemalang District Prosecutor's Office in investigating corruption can be classified as follows:

- Structural Constraints.

- Low salaries for civil servants, including prosecutors;

- The existence of sectoral and institutional egoism;

- The low quality and quantity of human resources, law enforcement officials;

- The budget provided is minimal and still very limited;

- Inadequate facilities and infrastructure.

- Cultural Constraints.

- There is a shy attitude among fellow government officials;

\footnotetext{
${ }^{21}$ The results of the author's interview with Fajar Seto Nugroho, $\mathrm{SH}, \mathrm{MH}$ as the Investigating Attorney at the Pemalang District Prosecutor's Office, on September 25, 2020.

${ }^{22}$ Adi Wibowo, Umar Ma'ruf, 2019, Substantial Justice In Handling Of Child Actors Klith, Jurnal Daulat Hukum, Vol. 2. No. 2, Universitas Islam Sultan Agung Semarang, p. 155 - 164.

${ }^{23}$ Agus Sularman, Umar Ma'ruf, 2017, Criminal Law System in Indonesia. Khaira Ummah Legal Journal, Corporate Criminal Liability to Victims of Crime, Vol. 12. No. 2 June 2017 Universitas Islam Sultan Agung Semarang: 387 - 396.
} 
- Lack of openness of the existing leadership in an agency so that the impression is that there are actions to protect corruption actors

- Low commitment to deal with corruption problems decisively and thoroughly;

- The attitude of ignorance or permissiveness of the majority of society towards efforts to eradicate corruption.

- Instrumental Constraints.

- The procedure that must be followed by an investigator in carrying out an investigation action requires a long time;

- Lack of extradition agreements with other countries. ${ }^{24}$

In the process of functioning of the law enforcement apparatus, there are 3 (three) important elements that influence, namely: 25

- Law enforcement institutions and various supporting facilities and infrastructure and institutional working mechanisms;

- Work culture related to the apparatus, including regarding the welfare of the apparatus, and

- Human Resources who support both institutional performance and regulating legal materials that are used as work standards, both material law and program law.

In order to overcome obstacles in preventing acts of corruption in the area of the Pemalang District Prosecutor's Office, efforts or solutions are made, including: 26 :

- Looking for the whereabouts of the witness and summoning him to provide information about the criminal act he heard, saw, and really knew.

- Procurement of personal qualities as prosecutors in the special criminal field (corruption crime).

- Conduct special education for assigned prosecutors and technical mastery of special criminal investigations.

- Providing assistance through the Civil and State Administration to other stakeholders in terms of budget and financial management in the Regional Work Unit itself from the start so that it can be maximally supervised the use of the budget used.

Law enforcers involved in eradicating criminal acts of corruption are investigators, public prosecutors and judges. The final determinant in eradicating corruption is the judge. However, judges cannot act actively outside the context of the case brought to trial by the public prosecutor, who is active in carrying out the process of investigation, investigation and prosecution is the prosecutor. It is not an exaggeration to say that the AGO is one of the determinants of success in eradicating criminal acts of corruption. Likewise, on the other hand, if up to now the eradication of corruption has failed, has not been successful or at least is

\footnotetext{
24 The results of the author's interview with Nunuk Wijayanti, SH as the Public Prosecutor of the Pemalang District Attorney, on September 25, 2020

25 Wijayanto and Ridwan Zachrie. (2011). Korupsi Mengerupsi Indonesia. Jakarta: PT. Gramedia. p. 3

26 The results of the author's interview with Mrs. Tati Vain Sitanggang, SH, MH. as Head of Pemalang District Attorney, on September 25, 2020.
} 
considered not optimal, then what is considered failed, unsuccessful or considered not optimal, one of which is the Prosecution. ${ }^{27}$

\section{Closing}

The implementation of law enforcement against perpetrators of corruption in the jurisdiction of the Pemalang District Prosecutor's Office carries out several stages in accordance with statutory regulations and the Prosecutor's SOP by prioritizing optimizing the return of state financial losses. Efforts made by the Pemalang District Prosecutor's Office in preventing the occurrence of criminal acts of corruption are through comprehensive policy efforts and comprehensive administrative reform in the form of privatization, deregulation and decentralization as well as providing assistance through the Civil and State Administration in carrying out financial management in the Apparatus Work Unit Areas in the Regency. And the factors that hinder enforcement in the jurisdiction of the Pemalang District Prosecutor's Office include the complexity of corruption cases, time constraints, and the minimum number of prosecutors who carry out investigations and the level of public legal awareness is still relatively low. The solution is the procurement of personnel who have the qualities as prosecutors in the special criminal field.

\section{References}

\section{Journals}

[1] Adi Wibowo, Umar Ma'ruf, 2019, Substantial Justice In Handling of Child Actors Klith, Jurnal Daulat Hukum, Vol. 2. No. 2, Universitas Islam Sultan Agung Semarang , p. 155 - 164.

[2] Agus Sularman, Umar Ma'ruf, 2017, Criminal Law System in Indonesia. Khaira Ummah Legal Journal, Corporate Criminal Accountability to Victims of Crime, Vol. 12. No. 2 June 2017 Universitas Islam Sultan Agung Semarang : 387 396.

[3] Aluysius Sutikna, Sri Kusriyah, Widayati. 2018. Implementation of Act No. 30 Year 2014 concerning Government Administration Against Corruption Crime Investigation Process at Rembang Police, Khaira Ummah Legal Journal Vol. 13. No. March 1, 2018.

[4] Rully Trie Prasetyo, Umar Ma'ruf, Anis Mashdurohatun, 2017, Corporate Crime in the Perspective of Criminal Law Formulation Policy, Jurnal Hukum Khaira Ummah Legal Journal, Vol 12, No.4, Universitas Islam Sultan Agung Semarang, p. 727-741.

[5] Usman. 2013, “Analisis Perkembangan Teori Hukum Pidana". Jurnal Ilmu Hukum.Volume 2 Nomor 1. Juni 2013.

[6] Zaenul Arifin, Sri Endah Wahyuningsih, Sri Kusriyah, 2017, The Process of Law Enforcement Against Criminal Actors, Khaira Ummah Legal Journal Vol. 12. No. 4 December 2017: 777-784

\footnotetext{
27 Luthfie, Salahudin. (2011). Kewenangan Kejaksaan Dalam Penyidikan Tindak Pidana Korupsi, Tesis Magister Ilmu Hukum Universitas Indonesia. p. 2.
} 


\section{Books}

[1] Bungi, Burhan. (2003). Analisa Data Penelitian Kualitatif, Pemahaman Filosofis dan Metodologis Kearah Penguasaan Modal Aplikasi. Jakarta: PT. Raja Grafindo Persada

[2] Hanitijo, Ronny. (1990). Metode Penelitian Hukum dan Jurimetri. Jakarta: Ghalia Indonesia

[3] Kristiana, Yudi. (2006). Independensi Kejaksaan dalam Penyidikan Korupsi. Bandung: PT Citra Aditya Bakti

[4] Luthfie, Salahudin. (2011). Kewenangan Kejaksaan Dalam Penyidikan Tindak Pidana Korupsi, Tesis Magister Ilmu Hukum Universitas Indonesia.

[5] Setiawan, Guntur. (2014). Impelemtasi dalam Birokrasi Pembangunan. Jakarta: Balai Pustaka

[6] Sri Endah Wahyuningsih and Rismanto. (2016). Kebijakan Penegakan Hukum Pidana Terhadap Penanggulangan Money Laundring Dalam Rangka Pembaharuan Hukum Pidana Di Indonesia, Universitas Islam Sultan Agung Semarang.

[7] Sudarto. (2010). Hukum Pidana dan Perkembangan Masyarakat. Bandung: Sinar Baru

[8] Sutarto. (2014). Hukum Acara Pidana Jilid I. Semarang: Universitas Diponegoro

[9] Teguh Sulista and Aria Zurnetti. (2011). Hukum Pidana: Horizon Baru Pasca Reformasi, Jakarta. PT. Raja Grafindo Persada

[10] Wijayanto and Ridwan Zachrie. (2011). Korupsi Mengerupsi Indonesia. Jakarta: PT. Gramedia 